\title{
ALAT FERMENTASI BAWANG PUTIH HITAM (BLACK GARLIC) UNTUK MENINGKATKAN KUALITAS DAN PRODUKSI BAGI INDUSTRI RUMAH TANGGA DI BANDAR LAMPUNG
}

\author{
Sri Purwiyanti ${ }^{*}$, Yetti Yuniati², Yul Martin ${ }^{3}$ \\ Jurusan Teknik Elektro Universitas Lampung, Bandar Lampung \\ Jl. Prof. Sumantri Brojonegoro No.1 Bandar Lampung 35145 \\ Penulis Korespodensi : sri.purwiyanti@eng.unila.ac.id
}

\begin{abstract}
Abstrak
Salah satu permasalahan yang ditemui pada industri rumah tangga produsen black garlic di Nunyai, Rajabasa adalah belum adanya peralatan produksi yang memadai, sehingga black garlic yang dihasilkan sedikit dengan kualitas yang kurang baik. Selama ini proses produksi dilakukan menggunakan rice cooker dengan suhu yang tidak tepat, tanpa pengatur waktu, dan kapasitas yang sedikit. Untuk mengatasi permasalahan tersebut, kegiatan pengabdian ini bertujuan untuk menghasilkan peralatan produksi berupa oven fermentasi listrik yang dilengkapi dengan pengatur suhu, pengatur waktu, dan dengan kapasitas lebih dari 5 kg. Kegiatan ini menyasar industri rumah tangga yang terdiri dari ibu-ibu rumah tangga di Nunyai, Rajabasa, Bandar Lampung. Kegiatan terbagi menjadi 5 tahap, yaitu tahap survei, tahap pemberian peralatan produksi, tahap pelatihan dan penyuluhan, serta tahap evaluasi. Penyuluhan akan mencakup materi edukasi tentang cara bagaimana meningkatkan kualitas black garlic yang diproduksi. Hasil yang didapatkan dari kegiatan ini adalah dapat meningkatkan produksi black garlic dengan kualitas yang baik, sehingga dapat menghasilkan peningkatan penghasilan bagi ibu-ibu rumah tangga pelaku industri rumah tangga sasaran.
\end{abstract}

Kata kunci: Black garlic, Pengabdian Kepada Masyarakat, Alat fermentasi

\section{Pendahuluan}

Bawang putih hitam (black garlic) adalah salah satu jenis makanan yang sedang naik daun saat ini. Makanan ini dipercaya dapat mengatasi berbagai masalah kesehatan. Beberapa manfaat black garlic adalah memerangi demam, menurunkan tekanan darah, dan detoksifikasi tubuh dari logam berlebih. Selain itu kandungan antioksidannya yang tinggi dapat digunakan untuk mencegah komplikasi diabetes, menurunkan kadar kolesterol, dan mengurangi resiko kanker. Black garlic banyak dijual bebas di pasar tradisional dan supermarket. Harga black garlic berkisar antara Rp 50.000 - Rp. 120.000 untuk berat 250 gram. Harga tersebut bervariasi tergantung dari kualitas black garlic tersebut.

Mengingat tingginya permintaan, usaha memproduksi black garlic adalah bisnis yang menjanjikan. Oleh karena proses pembuatanya cukup mudah, maka bisnis ini dapat dilakukan pada skala rumah tangga. Di desa Nunyai, kecamatan rajabasa, terdapat usaha kecil skala rumah tangga yang memproduksi black garlic. Usaha tersebut dibentuk oleh sekelompok ibu rumah tangga yang mengisi waktu luang dengan memproduksi black garlic untuk membantu perekonomian keluarga. Proses produksi masih menggunakan cara yang sederhana yaitu dengan menggunakan rice cooker sebagai alat fermentasi. Sekali produksi hanya dapat dihasilkan maksimal $2 \mathrm{~kg}$ black garlic. Oleh karena hasil produksi yang sangat sedikit, maka saat ini proses pemasaran masih dilakukan dari mulut ke mulut dengan memanfaatkan koneksi yang ada. Untuk itu perlu dicarikan jalan keluar untuk dapat meningkatkan hasil produksi dengan mutu yang baik.

Pada proses fermentasi black garlic dengan mutu terbaik, dibutuhkan beberapa tingkatkan suhu yang harus diatur dalam 3 tahap, yaitu $50-60{ }^{\circ} \mathrm{C}$ selama 10 jam. Lalu $70{ }^{\circ} \mathrm{C}$ dan selama 30 jam dan kemudian $80{ }^{\circ} \mathrm{C}$ selama 200 jam. Sehingga total waktu yang dibutuhkan adalah 240 jam atau 10 hari. Pada industri yang dilakukan mitra, proses fermentasi dalam pembuatan black garlic selama ini 
dilakukan dengan menggunakan rice cooker dengan kapasitas $2 \mathrm{~kg}$ setiap produksi. Permasalahan yang muncul adalah :

1. Suhu rice cooker tidak dapat diatur

Rice cooker hanya memiliki satu tingkatan suhu yaitu antara $70-80{ }^{\circ} \mathrm{C}$ yang tidak dapat diatur. Hal ini membuat hasil produksi black garlic memiliki mutu yang kurang baik.

2. Waktu produksi 15 hari

Dengan sistem yang sekarang, waktu yang dibutuhkan black garlic untuk matang adalah 15 hari. Ini adalah waktu yang relatif lama untuk memproduksi black garlic.

3. Kapasitas terbatas

Rice cooker memiliki kapasitas hanya 5 liter, dan untuk fermentasi black garlic hanya dapat diisi dengan $2 \mathrm{~kg}$ bawang putih saja. Tentunya hasil produksi ini sangat sedikit dan tidak dapat mengarah pasar yang lebih luas.

4. Kualitas kematangan tidak merata

Bentuk rice cooker yang berbentuk tabung, membuat posisi bawang di dalamnya bertumpuk, yang mengakibatkan hasil fermentasi menjadi tidak merata.

\section{Bahan dan Metode}

Tujuan dari kegiatan pengabdian kepada masyarakat ini adalah untuk menghasilkan oven fermentasi fermentasi untuk pembuatan black garlic yang dilengkapi dengan pengatur suhu dan pengatur waktu. Oven fermentasi akan terdiri dari beberapa tingkatan rak, sehingga produksi menjadi lebih banyak dengan kualitas kematangan yang merata. Dengan demikian diharapkan dapat meningkatkan hasil produksi black garlic agar dapat memenuhi pasar yang lebih luas, mempersingkat waktu produksi black garlic, dan mengedukasi pelaku industri agar dapat menghasilkan black garlic dengan mutu yang baik.

Manfaat yang dapat diharapkan setelah kegiatan ini selesai dilaksanakan adalah produsen industri rumah tangga blak garlic dapat menghasilkan produk yang lebih banyak, lebih berkualitas, dengan waktu produksi yang lebih singkat, sehingga dengan demikian dapat menghasilkan produk dengan harga jual yang bersaing. Tentunya hal ini dalam jangka panjang dapat meningkatkan pendapatan keluarga pelaku industri rumah tangga tersebut.

\section{A. Bawang putih hitam (black garluc)}

Bawang putih hitam merupakan bahan makanan kuno. Pertama kali dibuat di Korea sekitar 4.000 tahun, dan kini kembali digemari oleh pelaku gaya hidup sehat maupun ahli gizi. Para ilmuwan juga telah menemukan banyak manfaat kesehatan yang tidak ditemukan dalam bawang putih biasa.

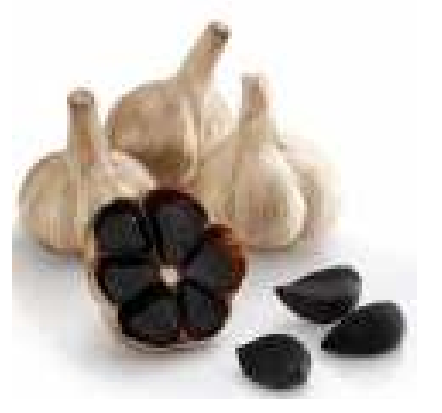

Gambar 1. Black garlic

Bawang putih hitam diolah melalui proses penuaan yang berlangsung sekitar 3 minggu. Diproses dalam kondisi lembab dan panas untuk membentuk karamel pada daging bawang, termasuk membentuk rasa yang lebih kuat. Gula dan asam amino menghasilkan melanoidin, membuat daging bawang putih menjadi hitam. Proses penuaan menguatkan manfaat kesehatan tradisional bawang putih, yang mencakup memerangi demam, menurunkan tekanan darah, dan detoksifikasi tubuh dari logam berlebih. Namun, bawang putih hitam dinilai mampu melakukannya lebih baik lagi. Beberapa khasiat utamanya diuraikan sebagai berikut.

Sebuah studi "Antioxidant Effect of Garlic and Aged Black Garlic in Animal Model of Type 2 Diabetes Mellitus" menemukan, bahwa bawang putih hitam memiliki kadar antioksidan yang lebih tinggi ketimbang bawang putih biasa. Tingginya kandungan tersebut, dapat digunakan untuk mencegah komplikasi diabetes. Antioksidan sendiri mampu melindungi integritas sel dan telah dikaitkan dengan menunda tanda-tanda penuaan. Menurunkan Kolesterol Bawang putih hitam mengandung konsentrasi tinggi dari senyawa S-allylcysteine, yang telah ditemukan mampu menurunkan kadar kolesterol.

Sebuah 2014 studi yang dimuat dalam Spandidos Publications menemukan, bahwa ekstrak bawang putih hitam tua dapat menghambat pertumbuhan jalur perkembangan kanker usus 
besar. Hal ini menunjukkan, bahwa ekstrak bawang putih hitam tua mungkin dapat digunakan dalam pencegahan dan pengobatan kanker usus besar di masa depan [Kompas, 2016].

\section{B. Sensor suhu DHT22}

Sensor suhu DHT22 merupakan sensor yang digunakan untuk mengukur suhu dan kelembaban udara disekitarnya. DHT22 menggunakan sensor kelembaban kapasitif dan thermistor untuk udara yang ada disekitarnya, dan mengirimkan hasil pengukurannya berupa sinyal digital melalui pin data. Sensor DHT22 memiliki tingkat kestabilan yang cukup tinggi dan memiliki fitur kalibrasi yang cukup akurat .

Sensor DHT22 merupakan sensor yang sangat banyak digunakan bersama Arduino, hal ini disebabkan karna sensor DHT22 memiliki kemampuan respon pembacaan data yang cepat, kemampuan anti-interference, ukurannya yang kecil, dan dengan transmisi sinyal hingga 20 meter. Sehingga sangat cocok digunakan untuk banyak aplikasi-aplikasi pengukuran suhu dan kelembaban.

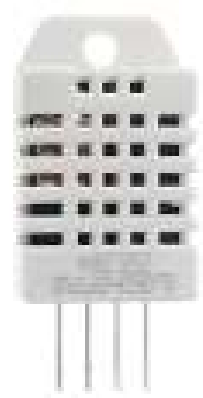

Gambar 2. Sensor suhu DHT22

Kegiatan ini dilakukan dalam beberapa tahapan sebegaimana diperlihatkan pada Gambar 3.

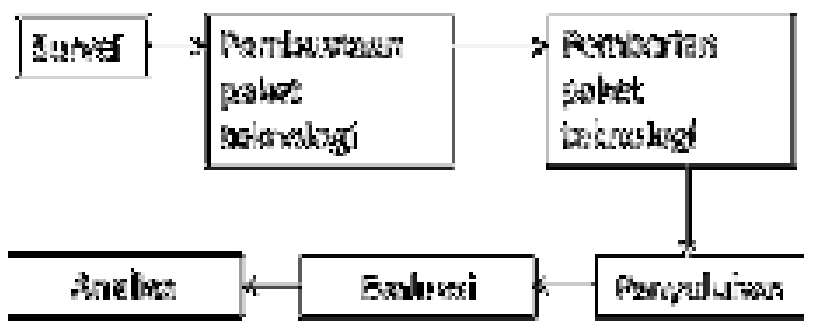

Gambar 3. Tahapan Pelaksanaan

\section{Tahap 1}

Survei untuk lebih mengidentifikasi profil industri rumah sasaran. Identifikasi diperlukan untuk melihat potensi-potensi yang dimiliki tempat diadakannya pengabdian. Potensi-potensi tersebut dapat berupa kelebihan maupun kekurangan yang ada di tempat tersebut. Dalam hal ini, identifikasi diperlukan untuk melihat permasalahan apa saja yang dialami pada pelaku home industri black garlic di wilayah tersebut. Tahap satu ini sudah dilaksanakan sehingga pemasalahan yang timbul telah berhasil ditampung untuk dapat dicarikan solusi. Kegiatan ini juga merupakan interaksi awal antara pihak dosen yang akan melakukan pengabdian dengan patra pelaku industri rumah tangga sasaran.

\section{Tahap 2}

Tahap kedua adalah tahap kelanjutan dari kegiatan identifikasi, yaitu pembuatan dan pemberian paket teknologi. Pada tahap ini dilakukan perancangan alat produksi berupa oven fermentasi yang memikili kualifikasi yang dapat mengatasi permasalahan dan memenuhi kebutuhan pelaku industri rumah tangga sasaran.

$\underline{\text { Tahap } 3}$

Tahap ketiga adalah penyuluhan dan pelatihan. Setelah diberikan paket teknologi berupa alat produksi, selanjutnya dilakukan pelatihan untuk mengoperasikan alat produksi tersebut. Pelatihan juga disertai cara melakukan perawatan dan perbaikan sederhana agar alat produksi dapat awet digunakan. Pada tahap ini juga dilakukan penyuluhan tentang metode memproduksi black garlic yang berkualitas. Dengan demikian diharapkan para pelaku industri rumah tangga sasaran dapat meningkatkan produksi dan harga jual produknya.

\section{Tahap 4}

Tahap keempat adalah tahap evaluasi yaitu tahap untuk menentukan keberhasilan dari kegiatan ini. Evaluasi dilakukan diakhir kegiatan yaitu dengan membandingkan kondisi sebelum dan setelah paket teknologi diberikan. Evaluasi digunakan untuk menilai apakah paket teknologi yang diberikan tapat sasaran atau tidak. Dari hasil evaluasi ini dapat dituliskan sebuah artikel yang membahas mengenai pengaruh pemberian paket teknologi dan edukasi pada kegiatan ini kepada hasil produksi dan pendapatan pelaku industri rumah tangga di daerah sasaran. 


\section{$\underline{\text { Tahap } 5}$}

Pada tahan ini dilakukan analisa data dari semua tahapan yang telah dilalui. Hasil analisa ini lalu dituangkan dalan bentuk pembuatan laporan kegiatan dan naskah publikasi.

\section{Hasil dan pembahasan}

Hasil kegiatan dapat diuraikan menjadi hasil kegiatan pada tiap tahapan kegiatan sebagai berikut:

\section{Hasil Kegiatan Tahap 1}

Kegiatan pada tahap ini bertujuan untuk melihat permasalahan apa saja yang dialami pada pelaku home industri black garlic di wilayah sasaran. Tahap satu ini tentunya sudah dilaksanakan sebelum kediatan PKM ini terwujud. sehingga pemasalahan yang timbul telah berhasil ditampung untuk dapat dicarikan solusi.

\section{Hasil Kegiatan Tahap 2}

Tahap kedua adalah pembuatan paket teknologi. Hasil dari tahap ini adalah telah berhasil terciptanya oven fermentasi black garlic sebagai mana yang diperlihatkan pada gambar berikut.
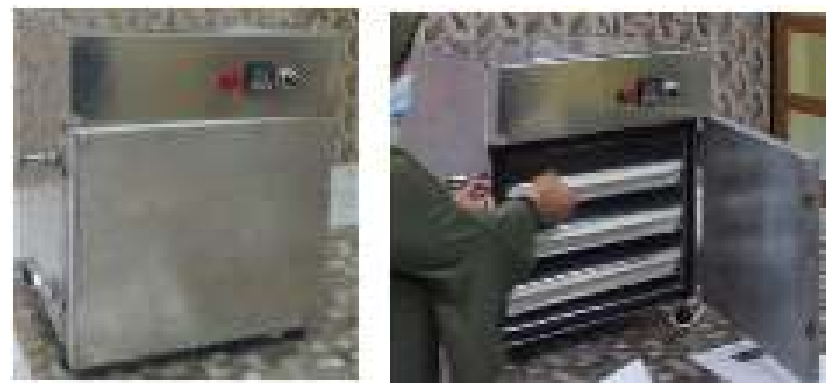

Gambar 4. Oven fermentasi yang dihasilkan

Spesifikasi dari oven yang dihasilkan adalah:

1. Dimensi $50 \times 50 \times 50 \mathrm{~cm}$

2. Daya listrik $400 \mathrm{~W}$

3. Suhu bisa diatur $40-90 \mathrm{C}$

4. Terdiri dari 3 rak

5. Terdapat 3 loyang. Tiap loyang berkapasitas $2 \mathrm{~kg}$ bawang putih.

6. Dengan suhu normal $70^{\circ} \mathrm{C}$, waktu produksi maksimal 12 hari.

7. Dilengkapi dengan petunjuk pemakaian.

\section{Hasil Kegiatan Tahap 3}

Tahap ketiga adalah penyuluhan dan pelatihan. Setelah diberikan paket teknologi berupa alat produksi, selanjutnya dilakukan pelatihan untuk mengoperasikan alat produksi tersebut. Pelatihan juga disertai cara melakukan perawatan dan perbaikan sederhana agar alat produksi dapat awet digunakan. Petunjuk pemakaian juga diberikan dalam bentuk naskah agar prosedur penggunaan alat dapat tetap dijalankan dengan baik.
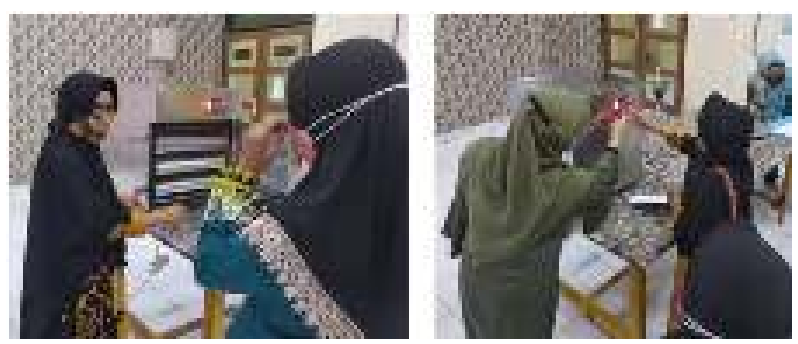

Gambar 6. Penyuluhan dan Pelatihan Penggunaan alat

\section{Hasil kegiatan tahap 4}

Tahap keempat adalah tahap evaluasi. Evaluasi dilakukan diakhir kegiatan yaitu dengan membandingkan kondisi sebelum dan setelah paket teknologi diberikan. Berdasarkan spesifikasi alat produksi yang telah dihasilkan, perbandingan kondisi tersebut dapat dilakukan dan ditampilkan pada Tabel 1.

Tabel 1. Kondisi sebelum dan setelah kegiatan

\begin{tabular}{|c|c|c|c|c|}
\hline \multirow[t]{2}{*}{ No } & \multirow[t]{2}{*}{ Parameter } & \multicolumn{2}{|c|}{ Kondisi } & \multirow[t]{2}{*}{ Keterangan } \\
\hline & & Sebelum & sesudah & \\
\hline 1. & $\begin{array}{l}\text { Kapasitas } \\
\text { alat }\end{array}$ & $1,5 \mathrm{~kg}$ & $6 \mathrm{~kg}$ & meningkat \\
\hline 2. & Suhu & $\begin{array}{l}\text { Tidak dapat } \\
\text { diatur, tidak } \\
\text { optimal, } \\
\text { tidak merata }\end{array}$ & $\begin{array}{l}\text { Dapat } \\
\text { diatur, } \\
\text { optimal, } \\
\text { merata }\end{array}$ & meningkat \\
\hline 3. & $\begin{array}{l}\text { Waktu } \\
\text { produksi }\end{array}$ & 15 hari & $\begin{array}{l}11-12 \\
\text { hari }\end{array}$ & $\begin{array}{l}\text { lebih } \\
\text { singkat }\end{array}$ \\
\hline 4. & $\begin{array}{l}\text { Mutu } \\
\text { produk }\end{array}$ & $\begin{array}{l}\text { Kematangan } \\
\text { tidak merata }\end{array}$ & merata & meningkat \\
\hline
\end{tabular}




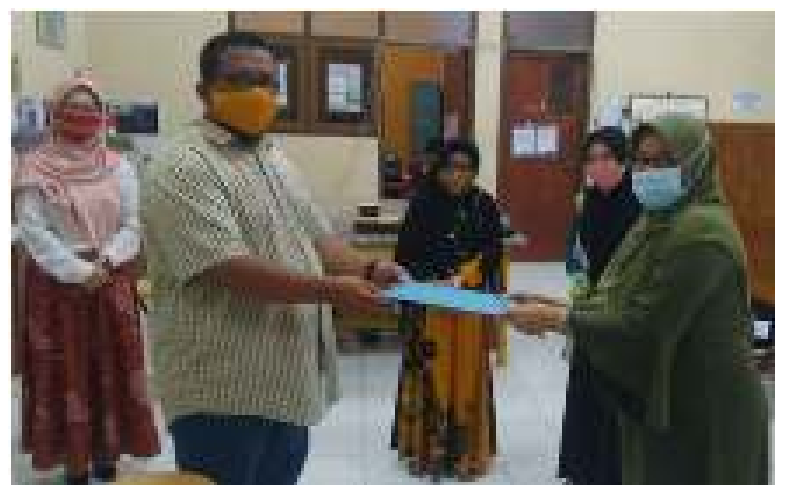

Gambar 7. Serah terima alat

\section{Hasil kegiatan tahap 5}

Pada tahap analisa ini, dilakukan analisa terhadap semua tahapan kegiatan, dari mulai tahap 1 sampai tahap 4. Semua tahapan telah dijalankan dengan lancar. Beberapa kendala yang muncul adalah:

1. Proses pembuatan alat memerlukan waktu yang jauh lebih lama dari estimasi waktu yang direncanakan. Diberlakukannya PSBB karena adanya virus covid 19 membuat proses pembelian komponen, diskusi dengan pengrajin pembuat bodi oven, dan diskusi perancangan rangkaian elektronika, semua dilakukan secara daring yang tentunya membutuhkan proses yang lebih panjang.

2. Pelaksanaan kegiatan semula direncanakan akan mengumpulkan seluruh ibu-ibu anggota industri rumah tangga sasaran. Namun PSBB yang diberlakukan juga membuat tidak memungkinkan dilakukannya kegiatan yang mengumpulkan orang banyak. Sehingga kegiatan hanya dilakukan dengan mengundang perwakilan dari kelompok tersebut beserta Ketua RT di lingkungan tersebut.

\section{Kesimpulan}

Walaupun dengan berbagai keterbatasan disebabkan diberlakukannya PSBB karena virus Covid 19, kegiatan pengabdian kepada masyarakat ini telah dilaksanakan dengan baik. Alat produksi telah berhasil dibuat dengan spesifikasi yang diinginkan. Kegiatan penyuluhan dan pelatihan juga telah dilaksanakan walaupun dengan peserta yang terbatas. Alat yang dihasilkan berhasil meningkatkan jumlah produksi dan kualitas produk yang dihasilkan. Hasil analisa kegiatan memperlihatkan bahwa kegiatan ini tepat sasaran dan sangat bermanfaat bagi mitra.

\section{Ucapan Terimakasih}

Terima kasih disampaikan kepada LPPM UNILA yang telah mendanai kegiatan ini melalui program DIPA BLU.

\section{Daftar Pustaka}

Bekker, J. G., Craig, I. K., \& Pistorius, P. C. (1999). Modeling and Simulation of Arc Furnace Process. ISIJ International, 39(1), 23-32.

Bezuidenhout, J. J., Eksteen, J. J., \& Bradshaw, S. M. (2009). Computational fluid dynamic modelling of an electric furnace used in the smelting of PGM containing concentrates. Minerals Engineering, 22(11), 995-1006.

Bhaktavatsalam, A. K., \& Choudhury, R. (1995). Specific Energy Consumption in The Steel Industry. Energy, 20(12), 1247-1250.

Camdali, U., \& Tunc, M. (2006). Steady State Heat Transfer of Ladle Furnace During Steel Production Process. Journal of Iron and Steel Research, International, 13(3), 18-20.

Fridman, A. (2008). Plasma Chemistry (p. 978). Cambridge: Cambridge University Press

Hovmand, S. (1995). Fluidized Bed Drying. In Mujumdar, A.S. (Ed.) Handbook of Industrial Drying (pp.195-248). 2nd Ed. New York: Marcel Dekker.

Istadi, I. (2006). Development of A Hybrid Artificial Neural Network - Genetic Algorithm for Modelling and Optimization of Dielectric-Barrier Discharge Plasma Reactor. PhD Thesis. Universiti Teknologi Malaysia

Primack, H.S. (1983). Method of Stabilizing Polyvalent Metal Solutions. US Patent No. 4,373,104

Roeva, O. (2012). Real-World Applications of Genetic Algorithm. In International Conference on Chemical and Material Engineering (pp. 25-30). Semarang, Indonesia: Department of Chemical Engineering, Diponegoro University.

Wang, Z., Wang, N. H., \& Li, T. (2011). Computational analysis of a twin-electrode DC submerged arc furnace for $\mathrm{MgO}$ crystal production. Journal of Materials Processing Technology, 211(3), 388395. 